\title{
Production of Joints Of Eucalyptus Sp. to Obtain Edge Glued Panels
}

\author{
Morgana Cristina França ${ }^{1}$ (D) \\ Linéia Roberta Zen ${ }^{1}$ \\ Claudio Gumane Francisco Juizo ${ }^{2,3}$ (1) \\ Victor Gonçalves Cremonez ${ }^{4^{*}}$ \\ Rosilani Trianoski ${ }^{4}$ (1) \\ Setsuo Iwakiri ${ }^{1}$ (1)
}

\begin{abstract}
This research aimed at evaluating the quality of bonded joints of Eucalyptus wood by using different faces and adhesives to produce EGP (Edge Glued Panels). Glue line shear specimens were obtained from bonded joints glued with PVAc (Polyvinyl Acetate) and EPI (Emulsion Polymer Isocyanate) adhesives, using pieces oriented with tangential, radial and intermediary faces, as well as the combination between them. The specimens were submitted to two pretreatments in order to simulate the use of joints in dry and wet environments. For shear tests, 12 treatments were obtained. The results indicated that the use of tangential $x$ tangential and tangential $x$ intermediary bonding faces and EPI adhesive presented better glue line shear strength for EGP in dry and wet pretreatments, respectively. The joints bonded in the radial $\mathrm{x}$ radial direction presented statistically inferior values when compared to the other treatments.
\end{abstract}

Keywords: Adhesives, Emulsion Polymer Isocyanate, Polyvinyl Acetate, Edge bonding.

\section{INTRODUCTION}

The timber industry has already been using Eucalyptus species, which have been a viable alternative to increase the supply of raw material to manufacture products from solid and reconstituted wood. However, this genus has its own limitations, typical of woods from fast-growing forests, such as growth stresses, which generates cracking and warping, as well as high anisotropy, limiting the use of wood in its solid form.

One way of minimizing or controlling these problems is the use of wood bonding technology, which enables the generation of products with greater dimensional stability and better distribution of mechanical strength, resulting in better quality and cost-benefit gains (IWAKIRI, 2005).

Among the various bonded products, Edge Glued Panels (EGP) are highlighted. They are produced from small pieces of wood (battens), which are edge glued and may or may not be face glued. They are used mainly in the furniture industry and civil construction to manufacturing floors and doors (IWAKIRI et al., 2016; ABIMCI, 2008). Another advantage of this type of panel is the possibility of using its parts with small or slight defects and waste from sawmills and other forest-based industries, thus increasing the yield by reusing a material that would be discarded (DANAWADE et al., 2014).

In EGP productive process, many factors influence the final quality, such as species, adhesive, amount of glue, pressing parameters, surface preparation, among others. Regarding the species, the physical, chemical and anatomical properties are highlighted. They are directly related to the mobility of the adhesive to the interior of the wood structure and the formation of "hooks" between the bonding faces (IWAKIRI, 2005). Marra (1992) corroborates the effect of adhesive on bonding faces as the author states that it occurs due to variation in the anatomical arrangement and, consequently, in the porosity of the different cutting planes.

\footnotetext{
${ }^{1}$ Universidade Federal do Parana (UFPR), Curitiba, PR, Brasil.

${ }^{2}$ Universidade Federal do Parana (UFPR), Departamento de Engenharia e Tecnologia Florestal, Curitiba, PR, Brasil.

${ }^{3}$ Instituto Superior Politécnico de Manica (ISPM), Divisão de Agricultura, Engenharia Florestal, Vanduzi, Manica, Mozambique.

${ }^{4}$ Universidade Federal do Parana (UFPR), Departamento de Engenharia e Tecnologia Florestal, Curitiba, PR, Brasil.
} 
In order to improve the quality of EGP, research has been carried out on the use of bonding faces (tangential, radial, or intermediary between tangential and radial) with the aim at verifying which face has the best response to bonding according to their chemical and anatomical structure and porosity (IWAKIRI et al., 2013). Thus, this study aims to evaluate the quality of bonded joints of Eucalyptus sp. when using different bonding faces and adhesives to produce EGP.

\section{MATERIAL AND METHODS}

Eucalyptus sp. wood from 15-year-old forest stands belonging to the company "MADEMAPE Madeiras", located in the municipality of Campina Grande do Sul (state of Paraná, Brazil), was used.

The wood was resawn into planks with dimensions of $25 \mathrm{~mm} \times 110 \mathrm{~mm} \times 2500 \mathrm{~mm}$ (thickness, width and length, respectively) and directed to pre-drying outdoors until reaching $22 \%$ moisture content. After pre-drying, the length of the planks was reduced to $650 \mathrm{~mm}$ for drying in a conventional pilot chamber up to $9 \%$ moisture.

From these planks, 24 radial pieces, 24 tangential pieces and 24 intermediary pieces, defined by the inclination of the growth rings in relation to the rays, were produced as suggested by Nennewitz et al. (2008). The pieces had dimensions of $20 \mathrm{~mm} \times 50 \mathrm{~mm} \times 300 \mathrm{~mm}$ (thickness, width and length, respectively). They were conditioned and later submitted to the production of bonded joints.

The experimental plan consisted of producing 12 treatments with different combinations of cutting orientations and two adhesives (Table 1).

Table 1. Experimental design used in face bonding of Eucalyptus sp.

\begin{tabular}{ccl} 
Treatment & Adhesive & \multicolumn{1}{c}{ Bonding Face } \\
\hline 1 & PVA & Intermediary x Intermediary \\
\hline 2 & PVA & Radial x Radial \\
3 & PVA & Tangential x Tangential \\
\hline 4 & PVA & Intermediary x Radial \\
\hline 5 & PVA & Radial x Tangential \\
\hline 6 & PVA & Tangential X Intermediary \\
\hline 7 & EPI & Intermediary x Intermediary \\
\hline 8 & EPI & Radial x Radial \\
\hline 9 & EPI & Tangential x Tangential \\
10 & EPI & Intermediary x Radial \\
\hline 11 & EPI & Radial x Tangential \\
\hline 12 & EPI & Tangential X Intermediary \\
\hline
\end{tabular}

PVA: Polyvinyl Acetate; EPI: Emulsion Polymer Isocyanate
For joint bonding, EPI and PVA adhesives applied with the amount of glue of $180 \mathrm{~g} / \mathrm{m}^{2}$ were used. After the adhesive application, the joints were pressed at room temperature (cold pressing) for one hour under the specific pressure of $0.65 \mathrm{MPa}$.

For each treatment, three replicates were carried out, totaling 36 bonded joints. After the bonding, the joints were air conditioned to completely cure the adhesives and obtain equilibrium moisture. Then, they were sectioned to manufacture the specimens.

The bonding quality of the different treatments proposed in the experimental design was evaluated through glue line shear test, according to standards EN 13353 (2003) and EN 13354 (2003), based on dry (equilibrium moisture) and wet $\left(24\right.$ hours of immersion in water at $20^{\circ} \mathrm{C}$ ) samples. Thirty specimens were tested per treatment (15 dry and 15 wet).

After determining the edge bonding shear strength, visual evaluation of the percentage of wood failure in the glue line was performed, as established by standard EN 314-1 (2004). In addition, fifth lower percentile was calculated and compared as suggested by standards EN 326-1 (2002) and EN 13353 (2003), respectively.

The results were submitted to Shapiro-Wilk and Bartlett's tests to verify data normality and homogeneity of variance, respectively. Then, ANOVA was applied to identify a significant difference between the treatments proposed and Tukey's test to compare the means. All tests were performed in the statistical program Statgraphics Centurion XVI.I, at a level of confidence of $95 \%$. The statistical design was $6 \times 2$ factorial arrangement with six bonding faces and two adhesives.

\section{RESULTS AND DISCUSSION}

Table 2 summarizes the analysis of variance for the two pretreatments performed. The sources of adhesive variation and bonding faces presented a significant difference at a level of significance of $5 \%$.

Table 2. Summary of the analysis of variance for dry and wet tests for bonded joints of Eucalyptus sp.

\begin{tabular}{ccc} 
Test & Source of variation & Significance of F \\
\multirow{3}{*}{ Dry } & Adhesive (A) & $23.79^{*}$ \\
& Bonding faces (B) & $9.82^{*}$ \\
& A x B & $2.23^{*}$ \\
Wet & Adhesive (A) & $52.91^{*}$ \\
& Bonding faces (B) & $7.23^{*}$ \\
& A x B & $0.56^{\text {ns }}$
\end{tabular}

${ }^{*}$ significant at a level of significance of $5 \%(\mathrm{p} \leq 0.05)$; ${ }^{\text {ns }}$ not significant ( $\left.p>0.05\right)$.

${ }^{*}$ significativo ao nível de $5 \%$ de significância $(p \leq 0,05)$; ${ }^{\text {ns }}$ não significativo $(p>0,05)$.

Regarding the adhesives used, bonded joints glued with EPI presented significantly superior values in relation to 
joints glued with PVA adhesive. Thus, to manufacture EGP that need more strength, EPI adhesive must be used. Correa (1997) explains that EPI strength is higher due to the fact that the cure of PVAc adhesive occurs by simple evaporation of the solvent (water), resulting in low strength bonding when exposed to high moisture conditions. The cure of EPI adhesive occurs by the reaction of its isocyanate groups with the hydroxyl groups of the wood, promoting stronger chemical adhesion. Iwakiri et al. (2015) also found greater strength in bonded joints using EPI adhesive than in joints using PVA.

For the bonding faces, the dry and wet pretreatments presented a statistical difference between the treatments. With regards to the source of variation that considers the interaction between adhesive and bonding faces, the adhesive influenced the strength of the bonded joints of the different bonding faces only for the pretreatment that had no contact with moisture.

Table 3 shows the mean values for shear strength of the bonded joints with PVA and EPI adhesive on the radial, tangential and intermediary (between tangential and radial) faces and the combinations between them.

For the dry pretreatment, it is worth noting that the results were statistically different, and the limit values are $7.93 \mathrm{MPa}$ and $12.77 \mathrm{MPa}$ for treatments 2 and 9 , respectively.
Lima et al. (2008) found shear values between 6.98 to 7.94 MPa for wood of Eucalyptus clones glued with PVAc, and Iwakiri et al. (2013) found values of $9.44 \mathrm{MPa}(\mathrm{PVA}-\mathrm{T} x \mathrm{~T}), 8.78 \mathrm{MPa}$ (PVA - R x R) and $8.91 \mathrm{MPa}(\mathrm{PVA}-\mathrm{R} \times \mathrm{T})$, when evaluating the strength of bonded joints of Eucalyptus benthamii wood glued with different adhesives and bonding faces.

For the EPI adhesive, Campelo et al. (2017) obtained limit values from 6.43 MPa to 7.81 MPa for the amount of glue of $180 \mathrm{~g} / \mathrm{m}^{2}$ and pressing times of 3 and 4 hours, respectively, when studying the feasibility of using Genipa americana wood to produce EGP. These results demonstrate that the shear values of the present study are higher than those found in the literature for most treatments.

The same tendency was observed for the dry and wet pretreatments. However, treatments 2 and 5 were numerically inferior to the others (4.62 MPa and $5.43 \mathrm{MPa}$, respectively), showing a statistical difference from treatment 9 , which was produced with EPI adhesive and tangential faces with mean glue line shear value of $8.84 \mathrm{MPa}$.

Campelo et al. (2017) found values of $4.20 \mathrm{MPa}$ and 5.30 MPa for EPI adhesive with the amount of glue of $180 \mathrm{~g} / \mathrm{m}^{2}$ and pressing times of 3 and 4 hours, respectively, for Genipa Americana wood.

Table 3. Mean values for shear strength, fifth lower percentile and wood failure of the 12 treatments studied.

\begin{tabular}{|c|c|c|c|c|c|c|}
\hline \multirow{2}{*}{ Treatment } & \multicolumn{3}{|c|}{ Dry } & \multicolumn{3}{|c|}{ Wet } \\
\hline & Shear (MPa) & 5th Percentile (MPa) & Failure (\%) & Shear (MPa) & 5th Percentile (MPa) & Failure (\%) \\
\hline $\begin{array}{c}1 \\
\text { PVA I x I }\end{array}$ & $\begin{array}{c}9.46 \mathrm{bcd} \\
(29.50)\end{array}$ & 5.38 & 58 & $\begin{array}{l}5.70 \mathrm{~cd} \\
(44.12)\end{array}$ & 2.17 & 27 \\
\hline $\begin{array}{c}2 \\
\text { PVA } \mathrm{R} x \mathrm{R}\end{array}$ & $\begin{array}{c}7.93 \mathrm{~d} \\
(26.58)\end{array}$ & 4.63 & 41 & $\begin{array}{c}4.68 \mathrm{~d} \\
(35.43)\end{array}$ & 2.56 & 33 \\
\hline $\begin{array}{c}3 \\
\text { PVA T } x \text { T }\end{array}$ & $\begin{array}{c}9.90 \mathrm{bcd} \\
(24.32)\end{array}$ & 6.62 & 51 & $\begin{array}{c}6.69 \mathrm{bcd} \\
(35.34)\end{array}$ & 2.91 & 35 \\
\hline $\begin{array}{c}4 \\
\text { PVA I x R }\end{array}$ & $\begin{array}{l}9.02 \mathrm{~cd} \\
(20.78)\end{array}$ & 6.12 & 61 & $\begin{array}{c}6.37 \mathrm{bcd} \\
(20.08)\end{array}$ & 4.53 & 46 \\
\hline $\begin{array}{c}5 \\
\text { PVA } \mathrm{R} \times \mathrm{T}\end{array}$ & $\begin{array}{c}9.91 \mathrm{bcd} \\
(27.59)\end{array}$ & 5.61 & 53 & $\begin{array}{c}5.43 \mathrm{~d} \\
(32.38)\end{array}$ & 2.91 & 26 \\
\hline $\begin{array}{c}6 \\
\text { PVA T x I }\end{array}$ & $\begin{array}{c}12.13 \mathrm{ab} \\
(25.48)\end{array}$ & 6.25 & 66 & $\begin{array}{c}6.54 \mathrm{bcd} \\
(36.93)\end{array}$ & 2.76 & 25 \\
\hline $\begin{array}{c}7 \\
\text { EPI I x I }\end{array}$ & $\begin{array}{c}11.93 \mathrm{ab} \\
(10.47)\end{array}$ & 10.08 & 95 & $\begin{array}{c}7.76 \mathrm{abc} \\
(8.97)\end{array}$ & 6.74 & 60 \\
\hline $\begin{array}{c}8 \\
\text { EPI } \mathrm{R} x \mathrm{R}\end{array}$ & $\begin{array}{l}8.45 \mathrm{~cd} \\
(23.51)\end{array}$ & 5.20 & 79 & $\begin{array}{c}5.96 \mathrm{bcd} \\
(17.09)\end{array}$ & 4.55 & 47 \\
\hline $\begin{array}{c}9 \\
\text { EPI T } x \text { T }\end{array}$ & $\begin{array}{l}12.77 \mathrm{a} \\
(26.40)\end{array}$ & 7.08 & 91 & $\begin{array}{c}8.84 \mathrm{a} \\
(24.41)\end{array}$ & 5.25 & 39 \\
\hline $\begin{array}{c}10 \\
\text { EPI I x R }\end{array}$ & $\begin{array}{c}12.12 \mathrm{ab} \\
(17.40)\end{array}$ & 8.62 & 81 & $\begin{array}{l}7.97 \mathrm{ab} \\
(13.10)\end{array}$ & 6.45 & 51 \\
\hline $\begin{array}{c}11 \\
\text { EPI R x T }\end{array}$ & $\begin{array}{c}11.04 \mathrm{abc} \\
(9.34)\end{array}$ & 9.41 & 70 & $\begin{array}{l}7.92 \mathrm{ab} \\
(14.51)\end{array}$ & 6.27 & 69 \\
\hline $\begin{array}{c}12 \\
\text { EPI T x I }\end{array}$ & $\begin{array}{c}11.91 \mathrm{ab} \\
(6.09)\end{array}$ & 11.04 & 72 & $\begin{array}{l}8.01 \mathrm{ab} \\
(12.52)\end{array}$ & 6.87 & 69 \\
\hline
\end{tabular}

Means followed by the same letter in the column do not statistically differ at a level of significance of $5 \%$. Values in parentheses indicate the coefficient of variation in percentage. Médias seguidas da mesma letra na coluna não diferem estatisticamente ao nível de $5 \%$ de significância. Valores entre parênteses indicam o coeficiente de variação em percentual. 
The difference between treatments 2 and 9 in both pretreatments was caused by the EPI adhesive since it is more resistant to debonding when it undergoes any mechanical action. Besides, the radial $\mathrm{x}$ radial bonding face generates weaker bonds between wood and adhesive due to the arrangement of the wood parenchyma.

Campelo et al. (2017) point out that comparative evaluations of the effects of EPI and PVA adhesives can be explained by EPI's chemical composition or formulation. The authors further note that both adhesives have vinyl acetate in their composition. On the one hand, acetate is polymerized in aqueous emulsion generating an aqueous dispersion of polyvinyl acetate in PVA; on the other, vinyl acetate is combined with polymeric isocyanate (diphenylmethane diisocyanate) in EPI. According to Clemente et al. (2014), diisocyanates provide rigidity and shear strength for polymers.

For the fifth lower percentile, all treatments reached the minimum requirement of $2.5 \mathrm{MPa}$, according to standard EN 13353 (2003), except for treatment 1, which was produced with PVA adhesive using intermediary faces, when subjected to immersion in water for 24 hours (Table 3 ).

Iwakiri et al. (2015) obtained values that ranged from 5.91 to $8.88 \mathrm{MPa}$ for dry pretreatment and limit values from 1.44 to $5.35 \mathrm{MPa}$ for wet treatment when evaluating the strength of bonded joints of Cryptomeria japonica and Sequoia sempervirens woods with different adhesives.

According to Table 3, the percentage of wood failure ranged from $41 \%$ to $91 \%$ (treatments 2 and 9 , respectively), considering the test performed with dry specimens. For the wet pretreatment, the variation of wood failure ranged from $25 \%$ to $69 \%$ (treatments 6 and 12, respectively).

The minimum requirement for wood failure is $40 \%$ according to standard EN 13353 (2003). Thus, most treatments have met the value specified by the standard. It is noteworthy that the percentage of wood failure between $0 \%$ and $25 \%$ indicates low adhesive strength and/or deficiency in the bonding process, such as smooth surface, low amount of glue applied, and high surface moisture; percentage between 50\% and 70\% indicates more suitable adhesion and adhesive properties; and percentage between $75 \%$ and $100 \%$ indicates stronger adhesion properties (MARRA, 1992).

When comparing our results with other studies, the research of Vital et al. (2006) is highlighted. They found percentages of wood failure of $35.73 \%$ and $51.64 \%$ for bonded joints of Eucalpytus saligna and E. grandis woods glued with PVAc adhesive, respectively. Iwakiri et al. (2013) found values of $16.88 \%, 51.07 \%$ and $40 \%$ for T x T, R x R and $\mathrm{T} x \mathrm{R}$ bonding faces glued with PVAc adhesive, respectively. Bila et al. (2016) found $0 \%$ of failure for all treatments that used PVA adhesive for six tropical Amazonian species. However, when the authors used EPI $\left(200 \mathrm{~g} / \mathrm{m}^{2}\right)$, the values ranged from $3.33 \%$ to $22.50 \%$ for Manilkara amazonica and Eschweilera odora, respectively.

The mean values of shear strength, fifth lower percentile and wood failure for the two pretreatments are presented in Table 4, considering only the adhesives and bonding faces.

Table 4. Mean values of the effects of adhesive and bonding faces on glue line shear strength, fifth lower percentile and wood failure.

\begin{tabular}{|c|c|c|c|c|c|c|}
\hline \multirow{2}{*}{ Treatment } & \multicolumn{3}{|c|}{ Dry } & \multicolumn{3}{|c|}{ Wet } \\
\hline & Shear (MPa) & 5th Percentile (MPa) & Failure (\%) & Shear (MPa) & 5th Percentile (MPa) & Failure (\%) \\
\hline \multicolumn{7}{|c|}{ Adhesive } \\
\hline PVA & $\begin{array}{c}9.72 \mathrm{~b} \\
(28.51)\end{array}$ & 5.13 & 55 & $\begin{array}{l}5.90 \mathrm{~b} \\
(35.84)\end{array}$ & 2.64 & 32 \\
\hline EPI & $\begin{array}{l}11.37 \mathrm{a} \\
(20.80)\end{array}$ & 8.10 & 81 & $\begin{array}{c}7.75 \mathrm{a} \\
(19.47)\end{array}$ & 5.20 & 56 \\
\hline \multicolumn{7}{|c|}{ Bonding faces } \\
\hline I x I & $\begin{array}{l}10.70 \mathrm{a} \\
(23.08)\end{array}$ & 7.87 & 76 & $\begin{array}{c}6.73 \mathrm{a} \\
(31.11)\end{array}$ & 2.72 & 43 \\
\hline $\mathrm{R} \times \mathrm{R}$ & $\begin{array}{c}8.19 \mathrm{~b} \\
(24.78)\end{array}$ & 4.15 & 60 & $\begin{array}{l}5.32 \mathrm{~b} \\
(28.22)\end{array}$ & 2.69 & 40 \\
\hline $\mathrm{T} \times \mathrm{T}$ & $\begin{array}{l}11.34 \mathrm{a} \\
(28.49)\end{array}$ & 6.33 & 71 & $\begin{array}{c}7.76 \mathrm{a} \\
(31.93)\end{array}$ & 3.22 & 37 \\
\hline $\mathrm{I} \times \mathrm{R}$ & $\begin{array}{l}10.57 \mathrm{a} \\
(23.81)\end{array}$ & 6.68 & 71 & $\begin{array}{c}7.17 \mathrm{a} \\
(19.64)\end{array}$ & 4.84 & 48 \\
\hline $\mathrm{R} \times \mathrm{T}$ & $\begin{array}{l}10.47 \mathrm{a} \\
(20.14)\end{array}$ & 7.33 & 62 & $\begin{array}{c}6.67 \mathrm{a} \\
(28.99)\end{array}$ & 3.20 & 47 \\
\hline $\mathrm{T} \times \mathrm{I}$ & $\begin{array}{l}12.02 \mathrm{a} \\
(18.37)\end{array}$ & 8.60 & 69 & $\begin{array}{l}7.27 \mathrm{a} \\
(27.01)\end{array}$ & 3.52 & 47 \\
\hline
\end{tabular}

Means followed by the same letter in the column do not statistically differ at a level of significance of 5\%. Values in parentheses indicate the coefficient of variation in percentage. Médias seguidas da mesma letra na coluna não diferem estatisticamente ao nível de $5 \%$ de significância. Valores entre parênteses indicam o coeficiente de variação em percentual. 
Considering the adhesive, the results obtained for EPI are statistically superior in relation to the results for PVA, for both pretreatments. Campelo et al. (2017) state that the best performance of the EPI adhesive can be justified by its intrinsic properties of adhesion to wood. The cure of this adhesive occurs by the reaction of its isocyanate groups with the hydroxyl groups of the wood, promoting chemical adhesion. In contrast, the cure of PVAc adhesive occurs through loss of water and union of its chemical structure (vinyl acetate molecules), characterizing a less resistant bonding. Campelo et al. (2017) found values of 6.43 MPa and 2.81 MPa for a dry condition and 4.20 MPa and $0.28 \mathrm{MPa}$ for a wet condition, using EPI and PVAc adhesives, respectively.

Regarding the bonding faces, the dry and wet pretreatments presented the same tendency for shear testing. Statistical difference was only highlighted for the treatment with faces radially bonded, being statistically inferior to the others (Table 4). This difference may be caused by the arrangement of the radial parenchyma, which does not provide the same strength when compared to the wood used in the tangential bonding face, since, according to Iwakiri et al. (2013), the exposure of the radial parenchyma on the tangential bonding face contributes to better penetration of the adhesive into the wood porous structure. Constitution of the growth rings, heartwood and sapwood variation, juvenile and reaction woods, wood grain and porosity may also influence the panel bonding efficiency, as previously reported by Iwakiri (2005). In addition, it is worth noting that the mean shear values in the treatments that had radial face in the bonded joint $(\mathrm{I} \times \mathrm{R}$, $\mathrm{T} x \mathrm{R}$ ) were inferior when compared to the others.

Iwakiri et al. (2013) explain that this variation can be attributed to the exposure of the radial parenchyma on the tangential and intermediary bonding faces, which contributes to better adhesive penetration in the wood porous structure and the formation of "hooks" for anchoring the faces of bonded pieces.

Regarding the wood failure in relation to the adhesive, the use of PVA provided lower mean values when compared to the results obtained for EPI. This result may have occurred since the bonding strength for PVAc was lower than the strength for EPI. Nonetheless, treatments did not reach the minimum limit of $40 \%$ established by the standard just when specimens were submerged in water for further testing.

Similarly, for the bonding faces, most treatments reached the values established by the standard, except for $\mathrm{T} x \mathrm{~T}$ bonding face in the wet pretreatment. In addition, it is worth noting that the percentages were relatively above the minimum value. Thus, it is possible to affirm that the treatments were in ideal conditions for the manufacture of bonded joints to produce EGP.

For the fifth lower percentile, all treatments reached higher mean values than $2.5 \mathrm{MPa}$, as established by standard EN 13353 (2003), considering both sources of variation and both pretreatments used.

Overall, considering the three factors analyzed, the most suitable treatment for dry environments is the one with two tangential faces and EPI adhesive (treatment 9). For wet environments, the most suitable treatment is the panel with tangential and intermediary faces glued with EPI adhesive (treatment 12). Regarding the adhesive, EPI presented better performance as regards the quality of bonding. Besides, all bonding faces are suitable for the production of EGP. The result on the bonding faces is extremely interesting, since it eliminates steps of the production process, as well as allows greater use of wood, confirming the great advantage of this product: added-value to by-products from other industries. As for its main applications, the use of EGP for internal use, especially in the furniture industry, and eventually in glued laminated timber or beams, is suggested, provided EPI adhesive is used.

\section{CONCLUSION}

The bonded joint with greater shear strength was the tangential $\mathrm{x}$ tangential one with EPI adhesive.

For dry and wet environments, the best composition was tangential $\mathrm{x}$ tangential and tangential $\mathrm{x}$ intermediary, respectively, with EPI adhesive.

For the fifth lower percentile and percentage of failure, the treatment performed with tangential $\mathrm{x}$ intermediary faces and EPI adhesive presented better mean values in the wet pretreatment.

Regarding the adhesives used, EPI presented higher strength when compared to PVAc.

For the bonding faces, the joints bonded in the radial $\mathrm{x}$ radial direction presented statistically inferior values when compared to the other treatments.

The mean values observed in this research were higher than those found in the literature, therefore presenting a potential for the use in industry.

\section{SUBMISSION STATUS}

Received: 5 January. 2018

Accepted: 30 March 2019

Associate editor: Divino Teixeira (1)

\section{CORRESPONDENCE TO}

\section{Rosilani Trianoski}

Universidade Federal do Paraná (UFPR), Departamento de Engenharia e Tecnologia Florestal, Avenida Lothário Meissner, 632, 80210-170, Curitiba, PR, Brasil.

e-mail: rosilani@ufpr.br 


\section{REFERENCES}

Associação brasileira da indústria da madeira processada mecanicamente - ABIMCI. Estudo setorial 2008. Curitiba, 2008. 52 p.

Bila NF, Iwakiri S, Trianoski R, Prata JG. Avaliação da qualidade de juntas coladas de seis espécies de madeiras tropicais da Amazônia. Revista Floresta 2016; 46(4): 455 - 464.

Campelo S, Iwakiri S, Trianoski R, Aguiar OR. Utilização da madeira de Genipa americana para produção de painéis de colagem lateral - EGP. Revista Floresta 2017; 47(1): 129 - 135.

Clemente M, Rocha RJ, Iha K, Rocco JAAF. Desenvolvimento de tecnologia de pré-polímeros na síntese de poliuretanos empregados em combustíveis sólidos. Química Nova 2014; 37(4): 982- 988 .

Corrêa C. Técnicas de colagem de madeira com adesivos vinílicos. Borden. Química Indústria e comércio Ltda, 1997. 68p.

Danawade BA, Malagi RR, Patil BS, Hanamapure RS. Effect of finger joint on flexural strength of teak wood. International Journal of Engineering and Technology 2014; 5(6): 4929-4937.

European Standard. EN 326-1 - Wood-based panels - Sampling, cutting and inspection - Part 1: Sampling and cutting of test pieces and expression of test results. Bruxelas: EN; 2002.

European Standard. EN 13353 - Solid wood panels (SWP) Requirements. Bruxelas: EN; 2003.

European Standard. EN 13354 - Solid wood panels - Bonding quality - Test Method - 11p. Bruxelas: EN; 2003.

European Standard. EN 314-1 - Plywood - Bonding quality - Part 1: Test methods. Bruxelas: EN; 2004.
Indústria Brasileira de Árvores - IBÁ. Relatório Ibá 2016: Brasília, 2016. 100 p.

Iwakiri, S, Trianoski R, Fonte APN, França MC, Lau PC, Molleken R. Potencial de uso de madeiras de Dinizia excelsa Ducke e Protium puncticulatum J.F.Macbr para produção de painéis EGP. Scientia Forestalis 2016; 44(111): 709-717.

Iwakiri S, Trianoski R, França RF, Gonçalves TAP, Loiola PL, Campelo SRF, Farias SMAP. Avaliação da resistência de juntas coladas da madeira de Cryptomeria japonica e Sequoia sempervirens com diferentes adesivos. Scientia Forestalis 2015; 43 (105): 19-26.

Iwakiri S, Trianoski R, Cunha AB; Prata JG, Hara M, Bila NF, Luis RCG, Araújo RD, Bôas BTV. Avaliação da resistência de juntas coladas da madeira de Eucalyptus benthamii com diferentes adesivos e faces de colagem. Scientia Forestalis 2013; 41(99): 411 - 416.

Iwakiri S. Painéis de Madeira reconstituída. 1. ed. Curitiba: FUPEF, 2005.

Lima KPL, Mori FA, Mendes LM, Trugilho PF, Mori CLS. O. Colagem da madeira de clones de Eucalyptus com três adesivos comerciais. Scientia Forestalis 2008; 36(77): 73-77.

Marra AA. Technology of wood bonding: principles in practice. New York: Van Nostrand Reinhold, 1992.

Nennewitz I, Nutsch W, Peschel P, Seifert G. Manual de tecnologia da madeira. Editora Blucher, 2008. 360p.

Tienne DLC, Nascimento AM, Garcia RA, Silva DB. Qualidade de adesão de juntas de madeira de Pinuscoladas em condições simuladas de serviço interna e externa. Floresta e Ambiente 2011; 18(1): 16-29.

Vital BR, Maciel AS, Lucia RMD. Qualidade de juntas coladas com lâminas de madeira oriundas de três regiões do tronco de Eucalyptus grandis, Eucalyptus saligna e Pinus elliottii. Revista Árvore 2006; 30(4): 637-644. 